Editorial

\title{
“Madame Bovary ce n'est pas moi"
}

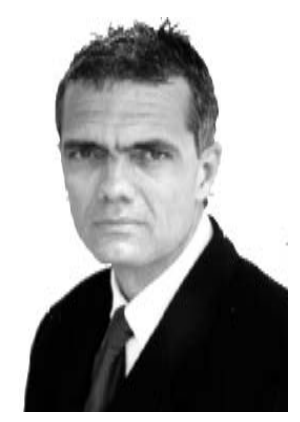

Marco Antonio Guimarães da Silva,Med.Dr.Sci.

marco@atlanticaedu.com.br

Longe do Brasil e, portanto, impedido de dar a habitual corrida ao redor da lagoa, vejo-me na obrigação, quase dever, de fazer longas caminhadas aqui em Paris, esperando, assim, que desse modo o corpo não se alargue, mais do que deve, abaixo da linha dos ombros. Em uma dessas caminhadas, fui levado a interromper indevidamente a atividade aeróbica para dar uma olhada em um título em português num velho e pequeno sebo. Deparei-me com o pequeno livro A morte de Ivan Ilitch. Não pude deixar de lembrar que essa novela de Tolstoi talvez tenha sido uma das histórias que mais me marcou. Filosoficamente, nos lembra quão ínfima é a nossa existência. Literariamente evidencia o magistral estilo do autor, que consegue narrar a dolorosa "via crucis” da personagem com a imparcialidade necessária para a construção de um universo literário especialíssimo. A narração permite que uma reflexão profunda sobre todas as etapas da vida do protagonista Ivan Ilitch, desvendando-se a si próprio, aconteçam em uma incômoda cumplicidade com o leitor, pela voz de um narrador que parece se manter o mais distante possível.

Iniciei, assim, esse editorial com a ousadia de emitir opinião literária, e, por isso mesmo, cometendo provavelmente uma heresia nessa área, para dizer que deveria, na condição de editor e supostamente formador de opinião, me comportar como o narrador da novela de Tolstoi, o que por motivos óbvios não consigo. Em outras palavras: creio que o ideal num editorial seria evitar os arroubos de sentimentalismo, deixando que o leitor por si só fizesse o seu próprio julgamento.

As inconveniências trazidas ao nosso cotidiano, pelos mais diversos setores, e tão debatidas por mim, em editoriais anteriores, criou a figura de um editor "cumulus nimbus", transfigurado, aqui, como um personagem pesado, forte nas suas convicções, mas que paradoxalmente é movido por desejos que não nascem espontaneamente. Eles se fortalecem da vontade de mudança que deve estar no desejo do outro.
O grito de revolta desse "personagem-editor" diante de tantos descalabros proporcionados no nosso cotidiano pode aqui, antagonicamente, conviver com uma aceitação à altura daquela vivida por Ivan Ilitch prestes a dar o seu suspiro derradeiro.

Sinto-me fascinado pela voz que dou ao meu "personagemeditor" e me reconheço igual a esse "outro". Guardando as devidas proporçôes, é claro, tal qual Flaubert se reconheceu semelhante à sua mais famosa personagem.

Não cultivo, entretanto, como Flaubert, qualquer tipo de culpa pelos amargos comentários que meu "personagemeditor" faz e pela ação que esses comentários possam vir a provocar no leitor. Não há aqui nenhum mal estar resultante desse estranho casamento de percepçóes táo distintas. Que me perdoe Flaubert!

Distante do manancial gerador de indignaçóes - o território brasileiro e seus alcaides -, não posso dar continuidade ao tema Indignaçóes, levantado por mim na edição anterior. Deixando que o lado "céu de brigadeiro" de meu personagemeditor predomine e lembrando também que sou editor de uma revista de fisioterapia, gostaria de informar que a Revista Fisioterapia Brasil irá trabalhar para, em médio prazo, conseguir indexação no Medline. Algumas providências já começaram a ser tomadas e entre elas está a criação de um comitê editorial assistente, composto pelos colegas Ana Paula Fontana, Anke Bergmann e André Luis dos Santos Silva, todos professores doutores com experiência na área de evidências. A orientação que essa editoria tem dado para o recém empossado comitê de assistentes editores é de que, num prazo a ser fixado brevemente, só se aceitem artigos cujos autores citados estejam previamente analisados. Os artigos resultantes de experiências clínicas devem também apresentar a respectiva aprovação do comitê de ética local. 